\title{
“A MAIOR FLOR DO MUNDO": FROM LITERATURE TO FILM - A STUDY IN COMPARATIVE LITERATURE
}

\author{
Luis Cardoso ${ }^{1 \mathrm{i}}$, \\ Andreia Baptista ${ }^{2}$ \\ ${ }^{1}$ Polytechnic Institute of Portalegre, \\ Centre for Comparative Studies - University of Lisbon, \\ Portugal \\ ${ }^{2}$ Basic Education (BA), \\ Polytechnic Institute of Portalegre, \\ Portugal
}

\begin{abstract}
:
This article is a comparative study between José Saramago's "A Maior Flor do Mundo", published in 2001, and its film adaptation made in 2007 by filmmaker Juan Pablo Etcheverry. Based on the discussion of the similarities and differences between the text and the film, it is intended to demonstrate that a film adaptation can add value to the narrative, through the inclusion of scenarios, characters, colours and sounds, which make it more understandable in the eyes of children. After a theoretical contextualization of the concepts of comparative literature, children's literature, adaptation and film adaptation, in the first part of this article we discuss the moral messages that José Saramago intends to transmit and the importance of this literary work in the child's individual, pedagogical and intellectual development. In the second part of the article, the characteristics of both works - literary and film - are compared, namely, the plot of both stories and the creative and moral sense of José Saramago and Juan Pablo Etcheverry.
\end{abstract}

Keywords: comparative literature, children's literature, José Saramago, adaptation

\section{Introduction}

Comparative Literature is commonly characterized as a comparison of two or more literary works. The multiple applications of this concept extend from the simple comparison between literary texts, through the comparison of literature in different nations, cultures or languages and can even cover the comparison between different types of arts, for example, investigating the relationship between films and works literary. Bolzan (2012) states that:

"Comparative Literature is the branch of literary studies responsible for establishing relations of interpretation between artistic expressions from different nations, as well as between the language

i Correspondence: email lmcardoso@ipportalegre.pt 
used in the expression of the work, and/or its translation into another artistic sphere, which can manifest itself through the music, theatre, cinema, poetry, prose, the way the themes are approached and influenced by the eyes of those who translate or who read." (Bolzan, 2012, p.92).

According to Carvalhal, Comparative Literature: "designates a form of literary investigation that confronts two or more works of literature" (2006, cit. By Bolzan, 2012, p.92). As for Peterle: "Comparative Literature provides the study of the dialogue between kinds of literature and other human expressions" (2011, cit. By Bolzan, 2012, p.92). Thus, comparative literature is a study of artisticliterary research, being a method of analysis that, in some way allows finding, in different contexts, similarities and differences, thus building meaning for reality. According to the perspective of Bolzan (2012), a comparatist aims to interpret the way the other speaks, thinks, sees and lives what he creates and the way he relates to the context that served as inspiration for creative production. Bolzan (2012) defined four ways of comparative studies: literary translation, reception aesthetics, intertextuality and literary poly systems. Literary translation is a way of expressing intercultural relations and between different works of literature, being a means of access to the artistic works of humanity, although subject to the translator's subjectivity. The aesthetics of the reception is related to the behaviour shown by the comparator between his works and those he is comparing. Intertextuality requires the comparator to make his analysis, leaving the context in which he feels comfortable and confronting dialogue with other subjects and theoretical references. Finally, literary poly systems are constituted by a set of norms and "laws" that structure the production of texts, inserted, in a local and temporal context.

One of the possible analyzes to be done in Comparative Literature is adaptation. The concept of adaptation according to Hattnher (2010) "has been used generically in several areas to describe operations of a transformation of texts, understood, from a post-modern perspective, not only as written materials but also as an attempt of representation in any type support." (Hattnher, 2010, p. 146). There are several forms of adaptation, we can adapt a literary work to a film, a play, or a graphic narrative, and in this article, we will focus on the concept of film adaptation. According to Marcel Silva and Rafael Freire (2007), "film adaptation is the process through which a work (literary, television, radio, etc.) has its constitutive elements transposed into a film narrative" (Silva e Freire, 2017, s / p). David Bordwell considers that "films emerged as stories made out of Narratives" (1985, cit. By Paiva, 2015, p. 25). Ann Dunn, Rosemary Huisman and Julian Murphet reflect that "the consequent adaptation of literary works happened naturally, although some theorists argue that cinema is not able to live up to literary work". (2005, cit. By Paiva, 2015, p. 26). It appears that literature and cinema go hand in hand for as long as the one in which cinema began to develop. Filmmakers quickly realized the narrative potential of literature for their productions; and cinema, once occupying the space of narration, provided greater aesthetic experimentation to writers.

Many film adaptations are based on children's literature, among which the traditional tales of the Grimm Brothers, Perrault and Hans Christian Andersen stand out. Through these stories, children retain moral values, immerse themselves in the world of fantasy and let their imagination run free, which is also a learning tool, and a stimulating way for them to play. Abramovich states that: 
"Reading, telling stories to children is being able to laugh, laugh, smile ... It is also to raise the imagination, to have curiosity answered concerning so many questions, to find ideas to solve questions (as the characters did ...). It is a possibility to discover the immense world of conflicts, impasses, solutions that we all live and go through (...)." (Abramovich, 1994, cit. By Chicoski, 2010, p. 22).

In Portugal, the field of literary education in the teaching of Portuguese seeks to establish an association between the formation of readers and their culture. The promotion of children's literature gains special relevance here in education for children's reading, where the National Reading Plan works as a pedagogical orientation and in which the work under study in this article is included.

One of the authors who also dedicated his attention to the universe of children's literature was José Saramago. This is the maximum exponent of Portuguese Literature having been the only Portuguese man to be awarded the Nobel Prize for Literature. In his vast literary work, the two styles that characterize Portuguese literature - lyric and satire - are visible, from the intimate and melancholic vision present in "Evangelho Segundo Jesus Cristo", to the criticism of the society of the time present in "O Memorial do Convento". Of all Saramago's literary work, his only work in Children's Literature stands out, "A Maior Flor do Mundo"/“The Greatest Flower in the World".

"The Greatest Flower in the World", as a children's literary work, depicts the story of a boy who one day ventured beyond his backyard and found a withered and almost dead flower. And his parents who realized that the child would have disappeared. Supported by neighbours, they ended up finding the boy under a large flower. It was the flower that, however, had grown with the effort of twenty water troughs that the boy had poured over him. As can be seen throughout the work, José Saramago devalues his ability to write children's stories, however, this literary work has seen its due value, through cinematographic adaptation, which contributed to a greater diffusion of the work, through a short film, directed by Juan Pablo Etcheverry in 2007.

\section{From literary narrative to film adaptation}

Children's literature is a branch of literature that had its first canons in the 18th century, with the publication of the first children's books. It is literature aimed at children that came to fill a gap in the literary field, since, until its appearance, only classical literature was available, whose characteristics did not meet their learning requirements. Through children's literature, with writing more specifically targeted to this audience, children, who now have a range of stories, tales and poems at their disposal. It plays an important role in the child's development, namely, in terms of language and familiarization with it, in its cognitive, emotional and social growth. According to Isabel Delgado (2010) "literature is a place of memory and formation for values, it allows you to grow in the knowledge of the language in its aesthetic aspect, it allows you to enrol in citizenship practices" (Delgado, 2010, p. 133). Children's literature is much more than a story, it is the projection that the author makes of them to reach the child, it is the illustrations that generate sensations, feelings and emotions, it is the intonation that is made at the time of reading, but above all, gives children the freedom to imagine, discover and fantasize, among words, phrases 
and illustrations. Mariana Fernandes (2017) states that "children's literature is an auxiliary means for the individual's holistic development since it will help the student to develop his imagination, to strengthen his intelligence and to clarify himself affectionately and socially" (Fernandes, 2017, p.3).

"The Greatest Flower in the World", by José Saramago, is the only work of children's literature by the writer and therefore gains a symbolic value in Portuguese and world literature because it is the only children's story written by the only Portuguese who received the Nobel Prize for Literature. José Saramago never thought of writing a story for children, and the editor himself asked him to do it. As a contemporary writer and with a very peculiar writing style, it is Saramago himself who, at the beginning of this narrative, devalues his abilities to write children's stories, feeling obliged as if to justify himself and excuse himself with the child reader. Saramago's attitude "not only signals the humility of the man that many considered arrogant but has the particularity of thus favouring the recognition and legitimation of this specific literary subsystem". (Mergulhão, 2012, p. 34). It is the one who says:

"Children's stories should be written in very simple words (...) I wish I knew how to write these stories (...) In addition to having to know how to choose words, there is a need for a certain way of telling, a very certain and very explained way, a lot of patience - and I at least lack patience, which I apologize for." (Saramago, 2014, p. 1)

Even though we are facing a narrative for children, José Saramago's peculiar and differentiating style of writing remains throughout the work, allowing the reader to read the story to develop his ability to interpret and enrich his vocabulary, recognizing the cognitive capacities, as an alternative to stories with a tendency towards excessive infantilization of children. For this reason, and although he demonstrates a humble posture when he assumes that he does not have the requirements to write stories for children, José Saramago makes explicit his will for this work to promote the development of children. Throughout the work, two distinct planes coexist in the narrative - that of the author and that of the narrator - that present themselves to the child reader in almost perfect articulation, being complex to separate the moments in which both occur. The author's plan arises from the beginning of the story until the beginning of the narrative itself, and this moment of the work is visible to the child through the illustrations of João Caetano. In this part of the story, the text is accompanied by the representation of an elderly man with a thinking look, sitting at the desk, next to a window and with a lamp illuminating a book on the desk - a personification of José Saramago. In the author's plan, José Saramago implies his recognition for teaching and teachers and his concern for the infant reader's ability to interpret, when he says "Now some difficult words will start to appear, but whoever doesn't know, should go to the dictionary or ask the teacher." (Saramago, 2014, p. 5). In agreement, Sara Silva (2019) states that "a little later in the report, again, as an aside, a preoccupation, almost pedagogical-didactic, with the difficulties that the younger readers may face in the face of vocabulary used in your story." (Silva, 2019, p. 35).

The transition from the author's plan to the narrator's plan occurs at the moment of the narrative in which the writer says "(..) my boy hero has his adventures settled outside the peaceful land where his parents live (...)" (Saramago, 2014, p. 6). This is one of the passages in which the complexity felt by the reader to distinguish the two planes of the narrative is perceived, 
surpassed, once again, by the illustrations of João Caetano, when representing next to the transcribed text, a boy who looks at the horizon through his ajar window. The narrator's plan takes place throughout the narrative itself, in which a boy appears who lives in a village and who one day left home in search of the unknown world. The distances travelled by the boy, who crosses rivers and mountains, are personified by the writer, to mobilize the child reader to discover worlds he does not know, challenging the limits of his knowledge and daring to have the freedom to imagine and fantasize. In the course of the narrative, the boy finds a "fallen" and "withered" flower, immediately concerned with finding a solution to save the small flower. So, he tried to find water and travelling the path between the top of the mountain and the river, he collected 20 shells of water with his own hands that he laid on the flower. At this stage, the writer hyperbolizes the size of the flower to symbolically associate it with the grandeur of the boy's achievement, as stated by Haoran Zhang (2019) “(..) to underline the child's heroic action, the narrator resorted to hyperbole to describe the boy's hard work done to save the flower (...) "(Zhang, 2019, p. 50). The narrative ends up returning to the author's plan, in which the writer asks a rhetorical question "who knows if I will ever read this story again, written by you who read me, but much more beautiful?" (Saramago, 2014, p. 26). This passage is a challenge for the child to explore his world of imagination and be able to give a personal touch to this story that was offered to him. Sara Silva (2019) wrote:

"The reality is that this issue seems to foresee the idea that no work, especially that aimed at children, ends as soon as their writing dies because whoever tells a story to a child offers a world to their imagination." (Silva, 2019, p. 36).

It is important now that we focus on the morals transmitted throughout history, more precisely on the message passed on to the reader. It is possible to identify in this story several symbolic messages that are important in the construction of a child's personality and his personal and social learning process. First of all, it is important to emphasize the moral transmitted to the reader in the ability of a boy to save a flower that grows in a size much larger than its height. This is a symbolic demonstration that children can overcome themselves and accomplish things bigger than their size, placing no limits on their imagination, on realizing the dream and not fearing the unknown. As Saramago, himself (2014) narrated in the story: “(...) people said that he left the village to go and do something much bigger than his size and than all sizes. And that is the moral of the story." (Saramago, 2014, p.23). We can also conclude that symbolically, the reader can establish an analogy of the flower with a child, the boy with an adult and the water shells that allow watering the flower with the values and education essential to the development of a child. Thus, it is up to the adult to assume, in a child's growth process, a role in the transmission of principles, in the promotion of multiple learnings and in the preparation to respond to the challenges of adult life.

A third and final moral message conveyed in this narrative focuses on the importance that a child, and therefore, the human being, must place in small things like a simple flower. To the extent that if we value what surrounds us, and which is often seen as something acquired, the risk of losing it decreases. Haoran Zhang (2019) states that: 
"The idea that there are structuring universal human values seems to be the starting point of a story that teaches us to value the simplest - and most fundamental - things of existence, but also solidarity and love for others, take it the form of a simple withered flower on dry ground. The child's morally positive image runs through the entire text, from the boy's decision to save the flower, watering it, even at the cost of sacrifice and personal suffering. It is a text whose message works for both adults and children because it teaches us to fight selfishness." (Zhang, 2019, p. 51).

All the messages understood and presented previously, went from the book to the cinema, with the film adaptation of the story by Juan Pablo Etcheverry, through the production of a short film, in the year 2007. The director, unlike the writer José Saramago, found a new potential that allowed to give another relief to the work, allowing to bring it closer to the child reader.

\section{Comparative analysis between the film adaptation and José Saramago's narrative}

A film adaptation is a process through which a literary work gains new life. According to Samantha Borges and André Vieira (2013), "since its inception, cinema has been in constant dialogue with literature. The use of text adaptation in different media is not a recent phenomenon, but literature finds a new form of an exhibition in cinema (...)". (Borges and Vieira, 2013, p.168). Cinema appropriates the literary narrative, the story, the narration, the characters, and locates them in film narration, but the director is completely free to, based on the literary work, compose a film scene. However, it should be noted that cinema does not obey the narrative faithfully, cinema does not copy the story, it adapts it. The film scene resulting from the adaptation of a narrative for cinema is, without a doubt, a different, original and unique result, compared to the literary work. For Naiara Araujo (2017), it is the relationships between literature, visual arts, media and music that allow "(...) to make literature one of the main sources of inspiration for film production. Through adaptation, countless narratives are "recreated" and "re-presented" to the public as being unpublished (...)". (Araujo, 2011, p.7). Some works have already had the privilege of going from book to film, marked the history of film adaptation and made the spectator fully enter the world of cinema. Often the literary text does not arouse a total enthusiasm in the reader and the film narrative comes to fill this gap and narrow the relationship that exists with reading. As Lucileine Avellaneda argues, "the literary text sometimes finds it difficult to find readers, the text on film appears as a rich and plural text, able to combine several languages, attracting a large part of the audience" (Avellaneda, 2017, s / p).

Possibly, the films that most marked us were the cinematographic adaptations made from the traditional tales of the Grimm Brothers, Perrault and Hans Christian Andersen, which gave life to fairy tales, the magic of princesses and the "were happily ever after" and that went from the oral tradition, of telling and listening to the cinema screens, with which the Walt Disney production arrested us. Lucileine Avellaneda (2017) wrote:

"The cinematographic productions of children's stories and children's literature stand out, which, structurally, are associated with narrative forms and the old tradition of telling and listening to stories (...). (...) These films became classics for enchanting generations - and forever marking childhood as such a magical and special moment. The close ties between film production and 
children's literature go back to the beginning of the transformation that the film industry has undergone, with animations and productions by Walt Disney." (Avellaneda, 2017, s / p)

Not all film adaptations were made from tales and stories of the big names in traditional children's literature and Walt Disney productions. Other great names in Portuguese literature have also seen their stories come to life in the world of cinema, as has our Nobel Prize for Literature, José Saramago, with his unique and wonderful work aimed at children "A Maior Flor do Mundo". It was in 2007 that Spanish director Juan Pablo Etcheverry brought the short film "La Flor Más Grande del Mundo" to the cinema screens, a film adaptation based on the work of José Saramago. With a duration of 10 minutes, this short film was produced by Cheila Loureiro and presents graphics that allude to the idea of figures in plasticine and cartoons, elaborated by Diego Mallo. With music by Emilio Aragón, in this short film the narration is done by José Saramago himself, even though for short periods, since most of it takes place without narration. It should be noted that this film was awarded 11 international prizes, among which the International Prize for Ecological and Nature Cinema of the Canary Islands stands out. Rogério Puga (2010) states that:

"The adaptation of the story and its transformation into a film or audiovisual narrative by Etcheverry raises questions about the authorship of the transformed text, which is obviously, and despite containing several excerpts from the original text, the responsibility of the screenwriter, but created from the original story. from Saramago. Etcheverry's creative freedom is obvious when constructing, with the cooperation of the Portuguese author, his version of The Greatest Flower in the World."(Puga, 2010, p. 472)

In this short film, the base story was adapted, the director applied his stamp and added details that are not found in the work written by José Saramago. In this way, the filmmaker managed to make the message implicit in the narrative more accessible to viewers' eyes, adding scenic elements that facilitate the understanding of the moral message transmitted in the narrative, such as, for example, the preservation of nature, expressed at the beginning of the short film, when the boy's father finds himself pulling out a tree and, ironically, it will be a flower that the child will water in order not to dry out and that, consequently, will protect him from the sun. Accordingly, Rogério Puga (2010) states that the short film “(...) sometimes gets closer, sometimes moves away from the starting text, with which it necessarily maintains a relationship of intertextuality not only literary but also cultural, leaving the ecological message reinforced in the short film." (Puga, 2010, p.472).

Establishing a comparison between the literary text and film, it is important to note, first of all, that the interpretive freedom of history, of naming the characters, creating scenarios and idealizing colours and shapes is significantly superior in the narrative compared to the short film. First of all, because in the narrative the children's reader only has the written history and illustrations that accompany it and in the short film, is in itself an interpretation of the narrative itself by the director who adapted it, it is limited to imagination, the construction of scenarios and the form of disposition of the characters, although some creative freedom is maintained due to the absence of narration in most film scenes. 
The similarities that stand out between the narrative and the short film are essentially related to the content of the story that is told in both works and the respective plot, such as the existence of a boy who crosses a river and the mountains so that, with your effort, when watering a flower that was withered on top of a hill, it is saved from total dryness. In agreement with Rogério Puga (2010):

"The action of both narratives is based, right from the start, both on the ecological journey of the boy hero, who moves away from his quiet village and his extended family, and also on the uncertain information that the narrator of the tale conveys when confessing his limited knowledge of the action he narrates." (Puga, 2010, p. 473)

Also in the field of similarities, the existence of two plans in the story stands out - that of the narrator and that of the story itself - and, in the short film, the narrator only speaks in the first person and only when we are in his plan, the plane of the story without any narration and without the appearance of the elderly person with glasses and a hat, a character that appears in the plane of the narrator.

Finally, it is important to highlight a similarity present in both works and which is related to the fact that the writer and the director sought to give an open outcome to the story, allowing the child reader and the viewer to let their imagination run free and through the dream to idealize that may be beyond the flower that is admirably observed by the population of the village/city. In this sense, Rogério Puga (2010) stated:

"Recalling the oral character(ising) of his writing style, Saramago, as well as the Galician screenwriter, seem to conclude in unison that whoever tells a story adds a point to him, and the Portuguese writer will continue to launch this challenge to his young people readers. The challenge of the dream and the journey that is written." (Puga, 2010, p. 481).

Between the narrative and the short film, there are symbolically notable differences, largely caused by the personal stamp that the director wanted to use in this film adaptation. From the outset, the most significant difference resides in the fact that in the literary work the two plans of the narrative are easily identifiable, which are presented separately, whereas in the short film the plan of the author and the plan of history appear mixed. It is, therefore, difficult to understand when one of the plans begins and the other ends, except for the existence of narration, which is the only identifying element of the moment when we are facing the narrator's plan. Other of the differences inherent to the personal nature that the director and illustrator gave to the cinematographic work is related to the mismatch between the illustrations in the book and those that are produced for film scenes. Accordingly, Rogério Puga (2010) considers "the 19 illustrations of the original story could have influenced Etcheverry when he adapted Saramago's story, but this did not happen, and the imagery of both narratives is distinct and characterized by different semantic fields and symbols" (Puga, 2010, p. 475). The beginning of the story is marked by specific differences between the narrative and the short film. In the cinematographic work, the appearance of a scarab is added, a representative element of nature and biodiversity, as Rogério Puga (2010) points out, "the protagonist of the short film has a new friend, the personified scarab whose 
presence opens and closes this visual narrative and whose activity, like that of the protagonist, is beneficial to the physical environment" (Puga, 2010, p.475). This beetle is observed through a magnifying glass by the elderly man with glasses and a hat, a character that symbolizes Saramago, as he declared in 2009: "I appear in it, wearing a hat and quite favoured in my age." (Saramago, 2009, cit. By Puga, 2010, p. 474).

In the literary work, the illustration of the said elderly person represents him writing while sitting at the desk of his office, but in the film work, the same elderly man observes the beetle and a boy and his father approaching in a pink car. As Rogério Puga (2010) reiterates "(..) in the short film, the plasticine writer resembles José Saramago and is not in the office, but on the street walking and writing, in an active attitude, while observing the world that surrounds you." (Puga, 2010, p. 476). In the narrative, the boy appears looking at the horizon through his window, starting from there the plane of the narrative, contrary to what happens in the short film, where the same boy accompanies his father on a trip to the countryside so that he last uproot a tree to decorate your yard.

Between the narration and the plot, two notable differences influence the transmission of the moral message of the story. The first is related to the fact that the narrative takes place in a village, while the film scenes take place in a cosmopolitan city under construction, the result of the deforestation of a dense area next to a forest. Because, as Rogério Puga (2010) states, "the universe (re) created by Etcheverry is a more modern world than that of the short story, as the family initially travels by car and lives in a grey area under construction between the rural and rural worlds. urban (...)" (Puga, 2010, p. 477). Rogério Puga (2010) further states that:

"In Etcheverry's short film, the environment and the rural community are different from the original models, as well as the" boy "family, which is only made up of his young parents, who are busy building a home in a newly built neighbourhood and community and that resemble a construction site populated by machinery and cranes and surrounded by arid fields in which the flower stands out." (Puga, 2010, p.478)

The second difference is present in the origin that caused the flower to wilt, namely, in the literary work that this origin was unknown and in the film work we learn that the flower has withered because the tree that gave it shade was pulled out by the boy's father. Accordingly, Rogério Puga (2010) proves that "the flower withers because the protagonist's father plucks the tree that provides shade to adorn his home garden, not thinking about the effect that such a decision has on the surrounding ecosystems" (Puga, 2010, p. 475). At the end of the story, two differences between the literary work and the short film are also identifiable, namely, when the parents go to look for the boy accompanied by the neighbours according to the narrative, and alone according to the film scene; and the moment the boy returns home, being acclaimed and applauded by the village population in written history and simply following his father's piggyback ride through the forest outside in the adapted story. As Rogério Puga (2010) states, "(..) in the short film, adult individualism is more prominent, as it is not the community looking for the boy who was absent, but only his parents (...)" (Puga, 2010, p. 473).

Focusing, now, on the moral message transmitted in the short film, it is important to highlight the care shown by the director in faithfully maintaining the two main moral messages 
that José Saramago intended to convey in the narrative. The moral inherent in the fact that the boy watered a flower much larger than his size is strictly maintained in the film scene in which the flower leaning over him creates a shadow that covers him, causing him to fall asleep. Rogério Puga (2010) argues that:

"It has now become commonplace to say that the novel or the film that does not narrate a trip, whether geographic, cultural or interior, is rare, and Saramago's short story and its film adaptation do just that: they represent the journey of delivery and the discoveries of the protagonist who, having no name, become universal and symbolize any child, towards inner growth, unconditional altruism and the impossibilities that only the dream gives shape." (Puga, 2010, 473).

The idea of valuing the little things that surround us, like a flower, is not only maintained but also accentuated by the director by demonstrating the importance that a single tree has in the ecosystem where it is inserted. Accordingly, Rogério Puga (2010) states that "the symbology of the two narratives is based on the botanical metaphor of friendship and disinterested delivery to the Other, in this case, Nature, which ends up returning the protection" (Puga, 2010, p. 475).

In addition to respecting the moral message conveyed in the literary work, the director dared to go further and transmit, through the adaptation of this story, an important and symbolic moral message inherent to the valorization of nature, as well as an intelligent social criticism. The idea of preserving the environment, valuing ecosystems and protecting biodiversity is present in numerous film scenes, among which the introduction of the beetle stands out; the tree that gave shade to the flower that had been uprooted by the boy's father; the flowers that the boy's neighbour watered; and the flowers themselves that were in the vase placed on the entrance wall of the house of the elderly with glasses and hat, which symbolically represents Saramago. The moral message and, consequently, social criticism, that the director wanted to convey in this film adaptation is presented to us by the accelerated and devastating way in which the city in which the boy lives grows, as well as, by the way, the land on the periphery of the city was to be deforested and the biodiversity of the forest then hitherto destroyed. Accordingly, Rogério Puga (2010) states that:

"The ecological message is obvious in both works, which can be interpreted in the light of the socalled Literary or Ecocritical Ecology, that is, the study of how literary writing represents, comments and influences the interaction between human beings and Nature through of themes that normally occupy the so-called Natural Sciences, such as industrialization, development, pollution and ecocide, among others." (Puga, 2010, 475).

As we have already seen, this short film brought an added value to the narrative, faithfully maintaining the moral messages that José Saramago intended to transmit to the child reader and adding a symbolic and pedagogical message related to the importance of nature preservation. For this reason, the short film is an important complement to the curricular application of this work and reinforces the role that this story can play in the individual, pedagogical, intellectual and social development of the child. 
Following on from the previous idea, Josiane Evangelista and Rosemari Calzavara (2016) affirm that "(...) cinema can be used as a didactic resource to stimulate and awaken in students an interest in reading novels or literary classics, such as fairy tales, which are increasingly present in the cinematographic language." (Evangelista and Calzavara, 2016, p. 216). Even though the short film is full of virtues in its curricular application, the truth is that if it is presented individually, we consider that there is a loss of the pedagogical value that Saramago's work has on the child's learning process, to the extent where "The Greatest Flower in the World" is an extraordinary means of promoting children's literature in the curricular plans for which this narrative is recommended. In short, the film adaptation should be seen by the teacher as a helping tool and not as the essence in the dissemination of this story in the curricular plans, since only the narrative and the book encourage reading and familiarize students with the importance of literature.

\section{Conclusion}

In this article, we carried out a study of comparative literature, in which an in-depth analysis was made of the film adaptation of José Saramago's work "A Maior Flor do Mundo", starting from a theoretical context that sensitizes the reader to the concepts of comparative literature, children's literature, adaptation and film adaptation. The methodology adopted for this comparative study began with the characterization of children's literature and cinematographic adaptation, as a starting point for a greater understanding of the specificities of each one and the interest they both represent in the process of learning and pedagogical, intellectual and linguistic development of the kid. In this sense, a literary study of Saramago's narrative was made that allowed us to understand his pedagogical objective and his moral message, and then to identify in the short film the same key elements and other additional elements that the director transposed onto the screen.

From the comparative study between the literary and film, we can say that "The Greatest Flower in the World" is as complex as what José Saramago said and at the same time as simple and accessible to children as what was intended by the author. The complexity inherent in the narrative, but which at the same time makes it challenging for the child reader, was made uncomplicated by the realization of the short film by Juan Pablo Etcheverry, where the difficult words were replaced by images, colours and sounds. Through this comparative study, it was possible to conclude that the plot is kept faithfully in the film work, adding characters, scenarios and symbolic details, such as the beetle. Additionally, we found that the achievement sought to deepen the moral message of the narrative, to which he added his moral message. Thus, it is concluded that the short film adds value to the narrative, insofar as it allowed it to internationalize, to make the story more accessible and didactic for the child audience.

From a symbolic and pedagogical point of view, narrative and its adaptation to cinema materialize a set of examples, values and humanist principles that are determinant in living in society and in the relationship between human beings and the environment in which they are inserted, such as the preservation of the environment. environment, the value of the family and the community and the importance of overcoming and pursuing our dreams. In addition to the symbolism transmitted, in both works the writer and the director sought to build an alternative 
to traditional stories and fairy tales, not overly infantilizing the child, but explicitly demonstrating that the reader and spectator have cognitive abilities to understand what transmitted to them, and these narratives constitute an intellectual and linguistic stimulus for them.

José Saramago used this as his only work of children's literature to criticize adults, present in the idea that the human being tends to lose the set of values and principles implicit in this work, which are often transmitted to him in childhood. This critical message is faithfully maintained in the short film, through the use of Saramago's voice, which provocatively ends the narrative by asking: "What if the stories for children became mandatory reading for adults? Would they be able to learn what they have been teaching for so long?" (Saramago, 2014).

\section{References}

Araujo, N. (2011). Cinema E Literatura: adaptação ou hipertextualização?. Littera Online, 6(3), 7. http://www.periodicoseletronicos.ufma.br/index.php/littera/article/view/449

Avellaneda, L. (2017). Das letras para o Cinema. CinemAção, s/p. https://cinemacao.com/2017/12/29/das-letras-para-o-cinema/

Bolzan, N. (2012). Literatura comparada: Uma Leitura Intersemiótica entre amar, verbo intransitivo, de Mário de Andrade e o filme Lição de Amor, de Eduardo Escorel. Revista Travessias, 6(1), 92-96. http://e-revista.unioeste.br/index.php/travessias/article/view/6107 Borges, S \& Vieira, A. (2013). Literatura Comparada e Adaptação Cinematográfica: A marcha de soldados de Salamina. Caderno Seminal Digital, 20(20), 168. https://www.epublicacoes.uerj.br/index.php/cadernoseminal/article/view/12020

Delgado, I. (2010). Ensinar Literatura, Promover Valores- uma proposta de leitura de A Maior Flor do Mundo, de José Saramago. Exedra, Atas do I EIELP. https://dialnet.unirioja.es/descarga/articulo/3398966.pdf

Evangelista, J \& Calzavara, R. (2016). Cinema e Literatura: do Clássico ao Moderno. Revista de Ensino, Educação e Ciências Humanas, 17(3), 216. https://revista.pgsskroton.com/index.php/ensino/article/view/4159

Fernandes, M. (2017). A Importância da Literatura Infantil no Desenvolvimento Socioemocional das Crianças. Dissertação de Mestrado, Instituto Politécnico de Coimbra. https://comum.rcaap.pt/handle/10400.26/23137

Hattnher, A. (2010). Quem mexeu no meu texto? Observações sobre Literatura e sua adaptação para outros suportes textuais. Revista Brasileira de Literatura Comparada, 16, 146. https://repositorio.unesp.br/handle/11449/122303

Mergulhão, T. (2019). Pelos caminhos do inefável: o percurso iniciático em A Maior Flor do Mundo, de José Saramago. In Araúso, R. e Oliveira, W. (org.). Literatura Infantojuvenil: diabruras, imaginação e deleite. $2^{\circ}$ ed. Vila Velha: Opção Editora, pp. 13- 25 (Brasil). https://comum.rcaap.pt/bitstream/10400.26/14305/1/Pelos\%20caminhos\%20do\%20inef\% C3\%A1vel.pdf 
Paiva, A. (2015). As Novas Estruturas Narrativas Cinematográficas No Cinema Português Realidade Ou Utopia?. Dissertação de Mestrado, Escola das Artes da Universidade Católica Portuguesa. https://repositorio.ucp.pt/handle/10400.14/19490

Puga, R. (2010). A Temática Da Viagem Ecológica Em A Maior Flor Do Mundo, De José Saramago, E Na Curta-Metragem A Flor Más Grande Do Mundo, De Juan Pablo $\begin{array}{lllll}\text { Etcheverry. Revista } & \text { 471-181. }\end{array}$ https://periodicos.fclar.unesp.br/letras/article/view/4709

Saramago, J. A Maior Flor do Mundo. Porto: Porto Editora, 2014

Silva, M \& Freire, R. (2007). Sobre uma Sociologia da Adaptação Fílmica: Um ensaio de Método. Crítica Cultural, 2(2). http://linguagem.unisul.br/paginas/ensino/pos/linguagem/criticacultural/0202/05.htm

Silva, S. (2019). A maior flor do mundo, de José Saramago, e as três composições visuais que já a acompanham. Tropelias \& Companhia, 33-45. http://repositorium.sdum.uminho.pt/handle/1822/63199

Zhang, H. (2019). Análise da Obra A Maior Flor do Mundo, de José Saramago. Dissertação de Mestrado, Universidade de Aveiro. https://ria.ua.pt/bitstream/10773/26699/1/Documento.pdf

Chicoski, R. (2010). Literatura Infantil. Guarapuava: Unicentro. http://repositorio.unicentro.br:8080/jspui/bitstream/123456789/824/5/Literatura\%20Infan til\%20-\%20Regina\%20Chicoski.pdf 
Creative Commons licensing terms

Author(s) will retain the copyright of their published articles agreeing that a Creative Commons Attribution 4.0 International License (CC BY 4.0) terms will be applied to their work. Under the terms of this license, no permission is required from the author(s) or publisher for members of the community to copy, distribute, transmit or adapt the article content, providing a proper, prominent and unambiguous attribution to the authors in a manner that makes clear that the materials are being reused under permission of a Creative Commons License. Views, opinions and conclusions expressed in this research article are views, opinions and conclusions of the author(s). and European Journal of Literature, Language and Linguistics Studies shall not be responsible or answerable for any loss, damage or liability caused in relation to/arising out of conflicts of interest, copyright violations and inappropriate or inaccurate use of any kind content related or integrated into the research work. All the published works are meeting the Open Access Publishing requirements and can be freely accessed, shared, modified, distributed and used in educational, commercial and non-commercial purposes under a Creative Commons Attribution 4.0 International License (CC BY 4.0). 